DOI: https://doi.org/10.15407/techned2019.05.049

\title{
THE PARAMETRIZATION METHOD OF GENERALIZED INDUCTION MOTOR USING THE FIELD ANALYSIS FOR DESIGN
}

$\quad$ Journal
Publisher
ISSN
Issue
Pages

\author{
Tekhnichna elektrodynamika \\ Institute of Electrodynamics National Academy of Science of Ukraine \\ 1607-7970 (print), 2218-1903 (online) \\ No 5, 2019 (September/Oktober) \\ $49-53$
}

\author{
Author \\ I.V. Golovan* \\ Institute of Electrodynamics National Academy of Sciences of Ukraine, \\ pr. Peremohy, 56, Kyiv, 03057, Ukraine, \\ e-mail:golovan_77@ukr.net \\ * ORCID ID : http://orcid.org/0000-0002-5250-6981
}

\begin{abstract}
The method of determining and mathematical representation of the relationship of the equivalent circuit parameters of an induction motor (IM) with its design and operational parameters using the results of field analysis has been proposed. This method has created a polynomial mathematical model of a system of electromagnetic parameters of a generalized IM, for design, which together with the IM circular mathematical model is an analogy of a field mathematical model. On the example of calculation, according to the obtained analogy of the IM field mathematical model, the IM design condition determines the degree of its adequacy to the results of the field analysis. References 9 , figure 1. table 1 .
\end{abstract}

Key words: induction motor, optimal design, macromodel, parameterization, experiment planning. 
Received: 06.12.2018

Accepted: 05.06.2019

Published: 01.08.2019

\section{References}

1. Vaskovskiy Yu. M. Field analysis of electrical machines. Kyiv: NTUU KPI, 2007. 192 p (Ukr)

2. Lei G., Zhu J., Guo Y., Liu C. at el. A review of design optimization methods for electrical machines. Energies. 2017. No 10. Pp.1962-1993. DOI: https://doi.org/10.3390/en10121962 3. Bramerdorfer G., Pyrhonen J., Tapia J. A., Cavagnino A. Modern electrical machine design optimization: techniques, trends and best practices. IEEE Trans. on Industrial Electronics. 2018. Vol. 65. Issue 10. Pp.930-941.

DOI:

https://doi.org/10.1109/TIE.2018.2801805

4. Ansys Inc.: http://www.ansys.com (accessed 15.11.2018)

5. Comsol multiphysics modeling and simulation software. URL: http://www.comsol.com/ (accessed 15.11.2018)

6. Radin V.I., Londin Y., Rozenknop V.D. The unified series of asynchronous motors Interelektro. Moskva: Energoatomizdat. 1990. 416p. (Rus)

7. Popovych O.M., Golovan I.V. Refinement of analysis operation of induction motors as part electromechanical systems using equivalenting field models using electrical circuits. Tekhnichn a Elektrodynamika . 2014. No 5. Pp. 113-115. (Ukr)

8. Ivobotenko B.A., Ilyinskiy N.F., Kopylov I.P. Planirovanie ekspirementa v elektromehanike. Moskva: Energiya. 1975. 184 p. (Rus)

9. Popovych O.M., Golovan I.V. Study of starting regimes of induction motors using equivalent parameters of quasi-3D field model. Tekhnichna Elektrodynamika. 2019. No 1. Pp. 34-37. (Ukr.) DOI:

https://doi.org/10.15407 /techned2019.01.034

\section{PDF}

